\title{
ENAH Gene
}

National Cancer Institute

\section{Source}

National Cancer Institute. ENAH Gene. NCI Thesaurus. Code C73551.

This gene is involved in the regulation of cytoskeletal structure. 